Primljen / Received: 20.10.2011. Ispravljen / Corrected: 12.2.2012.

Prihvaćen / Accepted: 21.2.2012.

Dostupno online / Available online: 15.3.2012.

\section{Requirements for experts conducting energy certification of buildings}

Professional paper

Nada Mardetko Škoro

\section{Requirements for experts conducting energy certification of buildings}

Energy audits and energy performance certification of buildings dominantly contribute to an increase in energy efficiency of buildings, and this through reduced use of energy and environmental protection. The need to ensure adequate quality of energy audits and energy certificates for buildings has resulted in development of a new profile of experts vested with highly specific competencies. An overview of requirements set for experts conducting energy audits and energy certification of buildings, compliant with European directives, is given. Conclusions reached on some European projects, and solutions applied in the Republic of Croatia, are also presented.

Key words:

energy efficiency, energy audit of buildings, energy certification of buildings, environmental protection

Stručni rad

\section{Nada Mardetko Škoro}

\section{Uvjeti za stručnjake koji provode energijsko certificiranje zgrada}

Energijski pregledi i energijsko certificiranje zgrada u najvećoj mjeri doprinosi povećanju energijske učinkovitosti zgrada kroz smanjenje potrošnje energije te zaštitu okoliša. Potreba osiguranja odgovarajuće kvalitete provedenih energijskih pregleda i izdanih energijskih certifikata zgrada inicirala je razvoj novog profila stručnjaka specifičnih kompetencija. U radu se daje pregled zahtjeva postavljenih na stručnjake koji provode energijske preglede i energijsko certificiranje zgrada prema europskim direktivama, zaključaka nekih europskih projekata te primijenjena rješenja u Republici Hrvatskoj.

Ključne riječi:

energijska učinkovitost, energijski pregled zgrada, energijsko certificiranje zgrada, zaštita okoliša

Fachbericht

Nada Mardetko Škoro

\section{Bedingungen für Fachleute, die Energiezertifizierungen von Gebäuden durchführen}

Energieuntersuchungen und -zertifizierungen von Gebäuden tragen der Steigerung der Energieeffizienz von Gebäuden durch Senkung des Energieverbrauchs sowie dem Umweltschutz im höchsten Maße bei. Der Bedarf an Sicherstellung einer entsprechenden Qualität der durchgeführten Energieuntersuchungen und ausgestellten Energiezertifikate für Gebäude hat zu einer Entwicklung eines neuen Profils von Fachleuten mit spezifischen Kompetenzen geführt. In der Arbeit wird eine Übersicht der an die Fachleute gestellten Ansprüche, die Energieuntersuchungen und -zertifizierungen von Gebäuden laut EU-Richtlinien, Anträgen einiger europäischer Projekte und angewandter Lösungen in der Republik Kroatien durchführen gegeben. 


\section{Introduction}

In order to ensure energy independence, and achieve environmental protection objectives, very high standards and goals have been set for the European Union countries. These goals include 20 percent reduction in energy consumption, 20 percent increase in the use of energy obtained from renewable sources, and 20 percent reduction in greenhouse gas emissions by 2020 [1]. Buildings have been singled out as the biggest individual consumers, but also as structures with the biggest energy-saving potential. For this reason, the building sector is ranking quite highly on the priority list of possible energy savings.

Energy audit and energy certification experts have been recognised as a new breed of experts, and their role is to assist in developing market aimed at achieving energy saving goals and decreasing greenhouse gas emissions by the year 2020. These experts need to have various competencies, including knowledge and skills in several engineering professions, as needed to efficiently conduct energy audits and energy certification of buildings.

A series of projects under the IEE (Intelligent Energy Europe Project) are being conducted with the goal of finding and analysing the obstacles, so that optimum solutions for achieving energy and environmental objectives can be found. Some of these projects include analysis of requirements to be met by experts who will perform tasks associated with energy audits and energy performance certification of buildings. They also provide recommendations on how to implement optimum and cost-effective energy saving measures.

This paper provides an overview of requirements set in European directives for experts that conduct energy audits and energy performance certification of buildings, a brief analysis of conclusions made on some European projects focusing on requirements for energy experts, and solutions that have been implemented in the Republic of Croatia.

\section{Energy audit and energy certification of buildings based on European directives}

The directive 2002/91/EC of the European Parliament and the Council of 16 December 2002 on the energy performance of buildings [2] (hereinafter: EPBD Directive) is the fundamental legislative instrument on energy efficiency of buildings, and it concerns the residential sector and the tertiary sector.

According to Article 10 of the EPBD Directive, Member States have to define in which way the certification of buildings, supply of appropriate recommendations, and inspection of boilers and air conditioning systems, will independently be conducted by qualified and/or authorized (accredited) experts, who are either self-employed or work in public or private companies or entities.

It is assumed that the independence of these experts, as based on objective criteria, will contribute to efforts made by
Member States to make energy savings in the building sector, while also ensuring better transparency for prospective owners and users with regard to energy performance on the EU real estate market.

It can be understood from the text of Article 10 of the EPBD Directive that no specific qualifications are needed for such experts, provided that they are independent and licensed for aforementioned duties. Since the EPBD Directive does not establish any licensing requirements, every country has the freedom to determine them on their own, taking into account national particularities, legislation and practices, so that best possible results can be achieved. Establishing licensing requirements can, but does not have to, be linked with control of the expert's competence through testing or development of a new qualification recognized on the national level [3].

Under these circumstances, legislators are presented with the task of determining conditions and criteria for experts who will perform energy performance certifications of buildings. These criteria can inter alia include:

- Level of education: college degree or secondary education,

- profession: for example architecture, civil engineering, mechanical engineering, electrical engineering,

- work method /methodology: an independent worker or an employee of a private or a public company,

- additional technical knowledge or abilities.

\section{According to the EPBD Directive the energy performance certificate is defined as:}

"A certificate recognized by a Member State or a legal entity appointed by the Member State, which submits energy features of a building or of an independent building unit calculated in accordance with the adopted methodology..."

The Directive 2010/31/EU of the European Parliament and the Council of 16 December 2002 on the energy performance of buildings (recast) [4] (hereinafter: EPBD I| Directive) strengthens and further expands the area covered by the EPBD Directive, while also introducing appropriate implementation mechanisms.

It is indicated in the preamble to the EPBD II Directive that, on the basis of objective criteria, qualified and/or authorised (accredited) experts need to be independent while conducting energy performance certification of buildings, and examining heating and air conditioning installations. An independent control mechanism for energy certificates for buildings, and for inspection of heating and air conditioning installations, must be established in every EU Member State so as to ensure high quality of services and to increase trust in services provided. Also, while implementing the EPBD I| Directive relating to qualified and/or authorized (accredited experts, the EU Member States are instructed to take into account the 2005/36/EC Directive of the European parliament and the Council of 7 September 2005 on the recognition of professional qualifications [5], i.e. to put into practice the principle of mutual 
recognition of experts in accordance with the EPBD II Directive. The European Commission has committed itself to continue with activities under the Intelligent Energy - Europe Project, with respect to provision of guidelines and recommendations regarding the rules for qualification (training) of these experts - professionals. It is specified that the experts should be authorized (accredited) taking into account their competences, and that the public should have full access to information about their qualification and accreditation.

The Directive 2006/32/EC of the European Parliament and the Council of 5 April 2006. on energy end-use efficiency and energy services and repealing Council Directive 93/76/EEC (hereinafter: Directive ESD) [6] has been passed with a basic goal to save energy by taking appropriate economic, feasible and rational measures. The aim is to save nine percent of energy over the next nine years.

The need to reduce energy consumption and greenhouse gas emissions, by promotion of energy efficiency in all energy consumption sectors, has strengthened a very important energy consumption measurement tool - energy audit.

To achieve a high level of technical competence, objectivity and reliability, the ESD Directive requires Member States to ensure, whenever necessary:

- availability of an appropriate qualification, authorization/ accreditation and/or certification scheme for energy auditors who will provide energy-related services, conduct energy audits, and give recommendations on how to increase energy efficiency,

- availability of efficient and high-quality energy audits intended to determine potential energy-efficiency improvement measures, that are implemented in an independent way for all end-users, including small households, commercial sector, and small and medium industrial consumers.

When it comes to energy audits, the emphasis is placed on high quality, efficiency and objectivity, while in case of audit experts the emphasis is on qualification, authorization/ certification, and independence.

According to the ESD Directive, an energy audit is defined as follows:

"An energy audit is a systematic procedure for gaining the appropriate knowledge of the existing energy consumption of a building or of a group of buildings, a technological process and/or industrial facility or for giving private or public services, that determines and evaluates the possibilities for energy savings and reports about conclusions".

It is specified in Article 12, Paragraph 3, of the ESD Directive that the energy performance certification of buildings, implemented in accordance with Article 7 of the EPBD Directive, is equally valid for purposes of energy auditing specified in the ESD Directive, which includes availability of efficient and high-quality energy auditing systems intended for determination of potential energy-efficiency improvement measures, and implemented independently for all end-users. By its validity, this certification is also equal to that for energy audits conducted on energy efficient public procurement projects, where public sector needs to take into account at least two requirements from the listed ones, including inter alia requirements for the use of energy audits and implementation of efficient recommendations resulting from such requirements.

\section{European projects in the field of energy efficiency of buildings}

SAVE Project AUDIT II (implemented from 2000 to 2003) was initiated and co-financed by the European Commission to enable analysis of different themes relating to energy audits, to establish a network of persons working in every country on energy audit programs, and to obtain reliable energy audit results that would provide to clients adequate information about implementation of energy-saving measures. The following agencies were designated as project partners: Ademe from France, Adene from Portugal, C.R.E.S from Greece, E.V.A from Austria, IFE from Norway, and Motiva from Finland [7, 3]. The project was conducted in 27 European Union countries.

In the end the project resulted in the Guidebook for Energy Audit Programme Project Developers.

According to the results obtained on the project, a proper energy audit should be conducted as follows:

- energy audits should be conducted by qualified experts (auditors),

- an audit license is given only to those who deliver clear and specific reports

- a mechanism for controlling work of the experts should be established, based on collection of all reports after which approval is given only to those that are clear and specific.

The following elements can be taken into account when determining requirements for experts who will be in charge of energy audits and energy certification of buildings: education, prequalification, authorization, and quality control. Figure 1 shows relations between prequalification, education, authorization, and quality control as determined in the scope of the project.

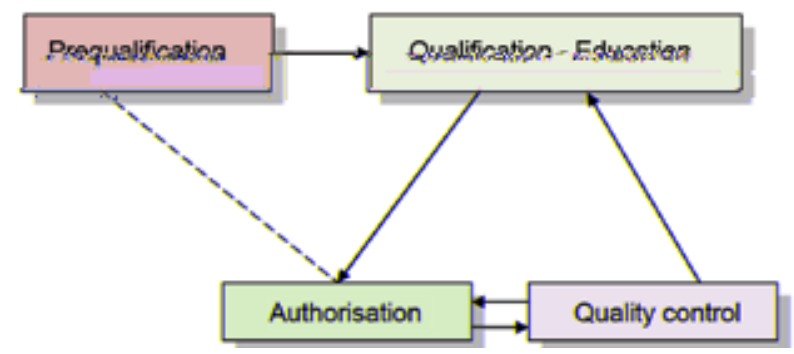

Figure 1. Relationship between prequalification, training, authorisation and quality control 
Prequalification means that some preliminary requirements are defined for the persons who apply for auditor training or authorisation. These requirements can be related to basic education and/or working experience. Different levels of prequalification may lead to different levels of training or different categories of authorisation. Cases without prequalification, with recommended prequalification, and with mandatory prequalification are considered. The prequalification implies a certain level of education, or a certain level of education and working experience, or a certain level of education, working experience, and references.

Training means that a certain group of persons is trained to conduct energy audits and energy performance certification of buildings. Various expert training cases are considered, as well as requirements in favour or against implementation of training. Cases without training, with voluntary training, with recommended training, and with mandatory training are considered.

Expert authorization implies granting approval to perform audits. The authorization can be given to either physical or legal persons.

The following cases of authorization are considered mandatory (based on regulations), semi-official (not official but based on some requirements), and unofficial (conducted by an association). Basic authorization alternatives are presented in Figure 2.

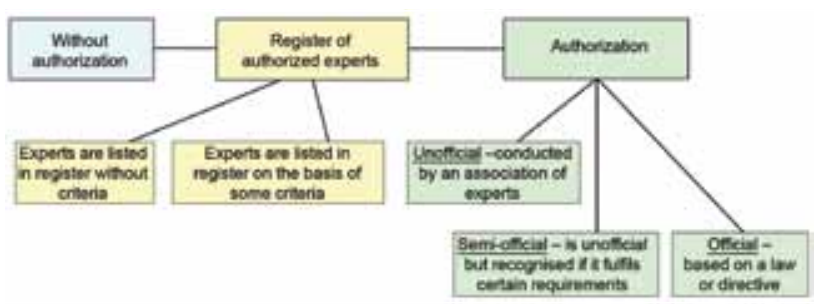

Figure 2. Basic authorization alternatives

Quality control of experts that perform energy audits and energy certification of buildings implies that an auditor's work is checked by a neutral person or entity. Cases without quality control, cases with random and non-systematic quality control, and cases with systematic quality control, are considered.

\section{Project recommendations}

Expert training is a crucial element, and should be mandatory. A special emphasis should be placed on a good concept of training, which should inter alia be based on the following assumptions:

- prequalification is needed as a precondition for training,

- training should contain technical elements that will show how existing expertise can be applied in energy audits for buildings,

- expert competence is confirmed by mandatory verification of knowledge, involving verification of theoretical and practical knowledge about conduct of energy audits,
- training quality should be taken into account and, in this respect, continuous checks and adjustments of training programmes should be made,

- appropriate topics from all professions should be included in the training programme and, in order to improve competence of experts, the training should be conducted as a continuous process.

Expert authorization is an adequate way for ensuring that the energy performance certification of buildings is conducted by professionals. During the authorisation process, the following recommendations should be taken into account:

- the duration of authorization should be limited, so as keep under control the number of auditors, and to give possibility to work only to those individuals who are actively providing the service. The register of quality controls should be updated yearly,

- the area of authority should be harmonized with technical education of experts and complexity of work, e.g. residential buildings, service-oriented buildings, industrial facilities, etc.,

- a yearly fee for authorized persons should be defined,

- other necessary elements that are the prerequisite for authorization of experts who will conduct energy performance certification of buildings, should be clearly specified.

Such authorizations should involve definition of clear rules, including procedures to be applied in cases of unprofessional conduct (e.g., cancellation of powers), and legal framework should be put in place so that the work of such experts can properly be checked.

Quality control is a necessary element for ensuring adequate quality of energy certification of buildings. The following recommendations are given with regard to quality control:

- quality control should be systematic, i.e. the whole process should be carefully planned,

- control should be based on verification/checking of reports on energy audit of buildings, with the possibility to conduct, when necessary, the quality control of such audits,

- the criteria according to which the reports to be checked are selected, should be clearly defined,

- reports should thoroughly be checked by professionals,

- the use of appropriate quality control tools must be anticipated so that the quality control can be conducted in a rational manner,

- the financing of quality control costs, as well as allocation of grants/subsidies, if any, should be secured within a reasonable deadline,

- quality control should be performed by consultants with experience in the relevant field/fields.

The CA-EPBD project (Concerted Action: Energy Performance of Buildings Directive) is being implemented since 2005. [8] and its goal is to find best solutions for implementation of 
the EPBD Directive through exchange of experience and best practice examples. All EU Member States, as well as Croatia and Norway, are taking part in the CA - EPBD Project.

The CA-EPBD Project deals with key themes contained in the EPBD Directive. One of them concerns specifications and requirements for the training of experts (professionals conducting certification of buildings) and persons responsible for the audit of heating and air conditioning installations (CT3). In the scope of this theme, requirements set for the experts are analyzed with respect to:

- accreditation/authorisation system,

- qualification: education, vocation, training, experience and - independence.

The following conclusions can be made based on results of research conducted under the CA-EPBD Project, phase II (the second phase of the Project was conducted from 2007 to 2010), with regard to requirements set by Member States for certification experts:

- experts for energy certification of buildings can be obtained by recruiting experts from existing professions (architects, engineers), and by providing appropriate further training for such experts,

- examination aimed at testing level of knowledge of such experts is an efficient mechanism leading toward harmonization of requirements for experts within EU countries,

- a good quality control must be put in place to check adequacy of persons conducting the training,

national rules of conduct must be set up for experts, including acceptance/recognition of independence requirement. Other

Table 1. Training programmes for experts conducting energy audits within the ENFORCE Project

\begin{tabular}{|c|c|c|}
\hline Country & Hours & Content of the training programme \\
\hline Italy & 120 & $\begin{array}{l}84 \text { hours of lectures; } 12 \text { hours of } \\
\text { individual work; } 12 \text { hours of building } \\
\text { visitations; } 8 \text { hours working with a } \\
\text { computer programme; } 4 \text { hours of } \\
\text { workshop }\end{array}$ \\
\hline Portugal & $\begin{array}{l}4 \times 21 \\
\text { and } \\
\text { evaluation }\end{array}$ & $\begin{array}{l}4 \text { modules that depend on working } \\
\text { domain: } \\
\text { - } \text { module } 1 \text { for residential and small } \\
\text { buildings for public use; } \\
\text { - } \text { module } 2 \text { for other non residential } \\
\text { buildings and for the audit of } \\
\text { heating and air conditioning } \\
\text { installations; } \\
\text { - } \quad \text { module } 3 \text { for interior air quality } \\
\text { control; } \\
\text { - } \text { module } 4 \text { for certification }\end{array}$ \\
\hline Spain & 120 & \\
\hline Greece & 120 & $\begin{array}{l}\text { Estimated training includes } 10 \text { themes } \\
\text { (modules), and the duration of each is } \\
12 \text { hours }\end{array}$ \\
\hline Slovenia & 120 & $\begin{array}{l}\text { Estimated training includes } 12 \text { modules, } \\
\text { and the duration of each is } 10 \text { hours }\end{array}$ \\
\hline
\end{tabular}

European directives, namely the professional qualifications directive [5], should also be taken into account,

- development of good administrative framework is a precondition for proper checking of work performed by the experts,

- it has been recommended that legal procedures for mutual recognition of experts among EU countries be initiated.

The ENFORCE project - European network for energy performance certification of buildings (2010.) [9]. The aim of the project is to give final consumers a means to obtain independent information and assistance in the energy certification of buildings, so as to remove non-technological obstacles that hinder the way toward an efficient and "intelligent" energy consumption network. In that respect, a trans-national network of trained energy auditors has been established to provide assistance to final consumers. The following countries are taking part in the project: Italy, Greece, Portugal, Slovenia and Spain.

An outcome of the project is the comparative analysis of the training and qualification programme for experts conducting energy audits and energy certification of buildings, including also comparative analysis of subsidy and assistance programs, and marketing campaigns.

Training and education, types of experts, quality control for the training programme

The attendance of the training programme in countries included in the Project has been organized in several ways: from compulsory attendance in Portugal to voluntary attendance in Spain. Requirements for experts focus on the level of education and professional experience. The need for appropriate technical knowledge and professional experience has been recognized in all countries. Under existing conditions, it is impossible to define a general training program because of great differences among countries. Present or past programs conducted in the scope of the ENFORCE project in Italy, Portugal, Spain, Greece and Slovenia, are presented in Table 1.

The analyses conducted in this field point to the conclusion that public authorities have to define minimum rules for experts and their qualifications, and this based on principles implying:

- independence of experts with respect to commercial interests of companies involved in the building procedure; this independence must be checkable and should be controlled by public entities,

- membership of experts in professional public associations of architects and engineers, levels $A$ and $B$,

- professional advancement of experts through mandatory participation in training programmes based on an educational programme to be set up by a public entity,

- final examination to be organized by the public entity responsible for educational programme; the same entity should keep the register of experts who passed the examination, 
- keeping register of energy certificates for buildings; this register should be kept by the entity responsible for keeping register of experts,

- audit checking based on random selection, so as to obtain written evidence confirming quality of energy certificates for buildings,

- further training of experts at regular intervals, so as to take into account technological developments.

Results obtained on the above projects with respect to requirements set for experts, can be summarized as follows:

- experts should have an appropriate technical education,

- a uniform expert training program should be put in place; the attendance should be mandatory, and periodical further training seminars, also mandatory, should be organized,

- pre-qualification of experts before the training positively influences the final learning result and the content of training,

- time-limited authorisation or accreditation of experts is a mechanism that enables proper control of the work of experts, and can directly be linked with achievement of good quality results in energy certification of buildings,

- control/checking of experts and institutions that handle the training of experts is mandatory,

- a network of independent qualified experts and companies should be created with the purpose of establishing connection with end-users on the European level,

- a data base of energy performance certificates must be created.

\section{Requirements for experts conducting energy audits of buildings in the Republic of Croatia}

Requirements for experts conducting energy audits of buildings, including regular audits of heating and air conditioning installations in buildings, are regulated by:

1. Law on efficient use of energy in final consumption (Official Gazette, Issue 152/08) [10],

2. Byelaw on energy audits for buildings (Official Gazette, Issue 5/11) [11],

3. Byelaw on requirements for the conduct of energy audits for buildings (Official Gazette, Issue 5/11) [12].

Law on efficient use of energy in final consumption [10] sets requirements for physical and legal persons who will conduct energy audits. These requirements inter alia specify education, work experience and a successfully finished training programme, and legal persons are required to have a permanently employed physical person.

Byelaw on energy audits of buildings [11] specifies that an energy audit of a building, or a control audit of heating or air conditioning installations, can only be conducted by persons authorized by the ministry (ministry in charge of energy sector) and registered with the Registry of persons authorised to conduct energy audits and control audits for heating and air conditioning installations in buildings.

An energy audit for structures, when such structures are buildings, can also be conducted by persons authorized to conduct energy audits of buildings with complex engineering systems (for the issuance of energy certificates for buildings), who are registered with the ministry in charge of construction for the conduct of energy audits and energy certification of buildings. The control audit of heating and air conditioning installations in buildings can also be carried out by persons authorized for energy audit of buildings with complex engineering systems in the segment relating to the mechanical portion of the engineering system.

Byelaw on requirements for the conduct of energy audits for buildings [12] specifies the types of authorizations and requirements for getting such authorizations. The ministry in charge of power sector issues authorizations for energy audits of buildings, and for control audits of heating and air conditioning installations in buildings. The authorization can be given to legal or physical persons, and is issued for the time period of three years.

Requirements for physical persons include:

- necessary education - at least undergraduate and/or graduate degree, or an integrated undergraduate and graduate degree, by which the degree holder acquires the academic title of "Master of Engineering" for a technical profession or, based on earlier educational programmes, an academic degree giving right to academic title of 'Graduate Engineer" for a technical profession, or an academic degree gained after completion of specialist graduates studies giving right to professional title of 'Specialist in Engineering",

- at least five years of working experience in the field of design, technical supervision on construction projects, building maintenance, audit of energy and/or process facilities, energy audit or energy services, or similar experience on other professional or research-oriented projects in the field of power generation (energetics);

- a successfully completed training programme for persons who conduct building energy audits and audits of heating systems and air conditioning installations in buildings.

A physical person is eligible to gain authorization to conduct heating and air conditioning system audits only if it has completed an appropriate education in the field of mechanical engineering. To be eligible for authorisation, a legal person must inter alia fulfil the registration requirement and the requirement to employ, on a permanent basis, at least one physical person who is authorized to conduct energy audits for buildings. To gain authorisation to conduct audits for heating and air conditioning systems in buildings, legal persons have to employ, on a permanent basis, at least one physical person holding a degree in engineering and authorized to conduct energy audits for buildings. 
Training Programme This 30 hour long programme is conceptualized in a way that, by attending the programme, an applicant can gain knowledge about the legislativeregulatory framework for carrying out energy audits in EU and in Croatia, about the methodology (steps) of audits consistent with Regulations on energy audits of buildings, about possible measures for improving the energy efficiency in buildings, and about preparation of reports on energy audits. The main emphasis is on the energy audit procedure and report preparation. In addition to the training programme, subsequent professional improvement programs must also be attended.

Conditions for experts conducting energy audits and energy performance certifications for buildings are specified in:

1. Law on physical planning and construction (Official Gazette, Issues 76/07, 38/09, 55/11 and 90/11) [13],

2. Byelaw on requirements and criteria for persons conducting energy audits and energy performance certification for buildings (Official Gazette, Issues 113/08 and 89/09) [14].

It is specified in the Law on Physical Planning and Construction that the certificate on energy characteristics of buildings is issued by an authorized individual, and that the authorization is issued by the ministry (ministry in charge of physical planning and construction). It is also specified in this law that an independent system for checking issuance of energy certificates for buildings must be put in place.

Types of authorizations and related requirements for physical and legal persons are set in the Byelaw on requirements and criteria for persons conducting energy audits and energy performance certification for buildings. Types of authorisations depend on technical complexity of buildings.

Thus, authorizations are issued for:

- energy performance certification of residential and non residential buildings with a simple engineering system,

- energy performance certification of residential and non residential buildings with a complex engineering system,

- energy audits of residential and non residential buildings with a simple engineering system and,

- energy audits of residential and non residential buildings with a complex engineering system in the segment relating to mechanical and electrical portions of the buildings engineering system, or in the segment relating to automatic regulation and management systems.

Authorizations are issued for the period of three years and can be obtained, depending on their type, by physical and/or legal persons. Requirements for physical persons inter alia include:

- necessaryeducationand profession-atleastundergraduate and/or graduate degree, or an integrated undergraduate and graduate degree, by which the degree holder acquires the academic title of "Master of Engineering" in the field of architecture, civil engineering, mechanical engineering or electrical engineering, or an academic degree gained after completion of specialist graduates studies giving right to professional title of "specialist" in one of the following professions: civil engineering, mechanical engineering, or electrical engineering;

- at least five years of working experience in the field of design, technical supervision on construction projects, maintenance and/or testing of civil engineering parts of buildings to ensure savings in energy and thermal protection, energy audit of buildings, testing functionality of energy systems in buildings or testing functionality of automatic regulation and management in buildings;

- a successfully completed training programme.

To be eligible for authorisation, a legal person must inter alia fulfil the registration requirement and the requirement to employ, on a permanent basis, at least one physical person who complies with requirements relating to education, profession, working experience, and who has successfully completed the training programme.

Physical persons are eligible for gaining authorisation to conduct energy audits for buildings with complex technical systems in the segments relating to mechanical and electrical engineering, or in the segment relating to automatic regulation and management systems, but only if such physical persons fulfil an additional requirement of having completed mechanical engineering education for energy audits of mechanical parts of buildings, or electrical engineering education for energy audits of electrical parts of buildings, or mechanical or electrical engineering education for energy audits of automatic regulation and management systems. To be eligible for such audits, legal persons must employ, on a permanent basis, at least one physical person who complies with these requirements.

Only legal persons are eligible to gain authorization to conduct energy certification for buildings equipped with complex technical systems.

Training Programme The training program is divided into two modules: $M 1$ and $M 2$, each with 40 hours of training. The modules are conceived in such a way that they provide knowledge about the legal-regulatory framework in the field of energy efficiency for buildings, while also offering additional knowledge in architecture, civil engineering, mechanical engineering and electrical engineering, as related to energy efficiency. Module 1 is compulsory for persons that are being trained for energy certification and audit of buildings equipped with simple technical systems, while additional training offered through Module 2 is compulsory for persons that are being qualified to conduct energy certification or audit (mechanical engineering segment, electrical engineering segment, or automatic regulation and management systems) for buildings equipped with complex technical systems. 
In addition to training programme, experts must also attend the professional improvement program sessions in order to acquire knowledge based on experience from past supervision of the work of authorized persons, and also to gain knowledge about technical advancements in their profession, about regulatory changes, etc.
The ministry (ministry in charge of physical planning and construction) issues approval for the conduct of the Education Programme (consisting of the Training Programme and the Professional Improvement Programme). The following institutions have approval to conduct this education: Faculty of Civil Engineering - University of Zagreb, Faculty of Mechanical

Table 2. A summary of requirements for persons conducting energy audits and energy certification of buildings.

\begin{tabular}{|c|c|c|c|c|c|c|c|c|c|}
\hline \multirow{2}{*}{ SERVICE } & \multirow{2}{*}{ AUTHORISATION } & \multirow{2}{*}{ PERSON } & \multicolumn{5}{|c|}{ VOCATION } & \multirow{2}{*}{ EXPERIENCE } & \multirow{2}{*}{ TRAINING } \\
\hline & & & $A$ & $\mathrm{G}$ & $\mathrm{S}$ & $E$ & $\mathrm{~T}$ & & \\
\hline $\begin{array}{l}\text { ECZ - JTS } \\
\text { EPZ - JTS }\end{array}$ & MGIPU & $\begin{array}{l}\text { physical } \\
\text { legal }\end{array}$ & $A$ & $\mathrm{G}$ & $\mathrm{S}$ & $E$ & & 5 yrs. & $\begin{array}{c}\text { M1 } \\
40 \text { hours }\end{array}$ \\
\hline ECZ - STS & MGIPU & pravna & $A$ & $\mathrm{G}$ & $\mathrm{S}$ & $E$ & & 5 yrs. & $\begin{array}{c}M 1+M 2 \\
40+40=80 \text { hours }\end{array}$ \\
\hline $\begin{array}{c}\text { EPZ - STS } \\
\text { Mechanical } \\
\text { engineering part }\end{array}$ & MGIPU & $\begin{array}{l}\text { physical } \\
\text { legal }\end{array}$ & & & $\mathrm{S}$ & & & 5 yrs. & $\begin{array}{c}M 1+M 2 \\
40+40=80 \text { hours }\end{array}$ \\
\hline $\begin{array}{c}\text { EPZ STS } \\
\text { Electrical } \\
\text { engineering part }\end{array}$ & MGIPU & $\begin{array}{l}\text { physical } \\
\text { legal }\end{array}$ & & & & $E$ & & 5 yrs. & $\begin{array}{c}M 1+M 2 \\
40+40=80 \text { hours }\end{array}$ \\
\hline $\begin{array}{l}\text { EPZ STS } \\
\text { ARiU }\end{array}$ & MGIPU & $\begin{array}{l}\text { physical } \\
\text { legal }\end{array}$ & & & $\mathrm{S}$ & $\mathrm{E}$ & & 5 yrs. & $\begin{array}{c}M 1+M 2 \\
40+40=80 \text { hours }\end{array}$ \\
\hline \multirow{2}{*}{ EPZ } & MINGO & $\begin{array}{c}\text { physical } \\
\text { legal }\end{array}$ & $A$ & $\mathrm{G}$ & $\mathrm{S}$ & $E$ & $\mathrm{~T}$ & 5 yrs. & $\begin{array}{c}\mathrm{PI} \\
30 \text { hours }\end{array}$ \\
\hline & MGIPU & $\begin{array}{l}\text { physical } \\
\text { legal }\end{array}$ & $A$ & $\mathrm{G}$ & $\mathrm{S}$ & $E$ & & 5 yrs. & $\begin{array}{c}M 1+M 2 \\
40+40=80 \text { hours }\end{array}$ \\
\hline \multirow{2}{*}{ PSGiK } & MINGO & $\begin{array}{l}\text { physical } \\
\text { legal }\end{array}$ & & & $\mathrm{S}$ & & & 5 yrs. & $\begin{array}{c}\mathrm{PI} \\
30 \text { hours }\end{array}$ \\
\hline & MGIPU & $\begin{array}{l}\text { physical } \\
\text { legal }\end{array}$ & & & $\mathrm{S}$ & & & 5 yrs. & $\begin{array}{c}M 1+M 2 \\
40+40=80 \text { hours }\end{array}$ \\
\hline \multicolumn{10}{|l|}{ Abbreviations: } \\
\hline $\mathrm{ECZ}-\mathrm{JTS}$ & \multicolumn{9}{|c|}{ Energy performance certification of buildings with simple en } \\
\hline EPZ - JTS & \multicolumn{9}{|c|}{ Energy audit of buildings with simple engineering systems } \\
\hline ECZ - STS & \multicolumn{9}{|c|}{ Energy certification of buildings with complex engineering systems } \\
\hline $\begin{array}{r}\text { EPZ - STS } \\
\text { Mechanical } \\
\text { engineering part }\end{array}$ & \multicolumn{9}{|c|}{ Energy audit of buildings with complex engineering part - mechanical engineering part of the engineering system } \\
\hline $\begin{array}{r}\text { EPZ STS } \\
\text { Electrical } \\
\text { engineering part. }\end{array}$ & \multicolumn{9}{|c|}{ Energy audit of buildings with complex engineering part - electrical engineering part of the engineering system } \\
\hline $\begin{array}{r}\text { EPZ STS } \\
\text { ARIU }\end{array}$ & \multicolumn{9}{|c|}{ Energy audit of buildings with complex engineering systems - automatic regulation and management system } \\
\hline EPZ & \multicolumn{9}{|c|}{ Energy audit of buildings conducted because of the need for energy management } \\
\hline PSGiK & \multicolumn{9}{|c|}{$\begin{array}{l}\text { Audit of heating and air conditioning installations, conducted in regular time intervals as a part of the energy } \\
\text { performance certification of buildings }\end{array}$} \\
\hline MGIPU & \multicolumn{9}{|c|}{ Ministry of Construction and Physical Planning } \\
\hline MINGO & \multicolumn{9}{|c|}{ Ministry of Economy } \\
\hline$M 1, M 2$ & \multicolumn{9}{|c|}{$\begin{array}{l}\text { Modules based on Education Programme that have been specified in the Byelaw on requirements and criteria for } \\
\text { persons conducting energy audits and energy performance certification for buildings }\end{array}$} \\
\hline $\mathrm{PI}$ & \multicolumn{9}{|c|}{$\begin{array}{l}\text { Education Programme specified in the Byelaw on requirements for the conduct of energy audits for buildings by } \\
\text { experts conducting audits of heating and air conditioning systems in buildings }\end{array}$} \\
\hline $\begin{array}{l}\text { A } \\
\text { G } \\
\text { S } \\
\text { E } \\
\text { T }\end{array}$ & \multicolumn{9}{|c|}{$\begin{array}{l}\text { Architectural profession } \\
\text { Civil engineering profession } \\
\text { Mechanical engineering profession } \\
\text { Electrical engineering profession } \\
\text { Engineering profession (for technical professions other than A, G, S and E) }\end{array}$} \\
\hline
\end{tabular}


Engineering and Naval Architecture - University of Zagreb, Energy Institute Hrvoje Požar, Brodarski institut d.o.o. (Naval Institute) - Zagreb, Croatian Chamber of Mechanical Engineers, Society of Civil Engineers - Zagreb, Faculty of Engineering - University of Rijeka, Polytechnics - Slavonski Brod, and Faculty of Electrical Engineering, Mechanical Engineering and Naval Architecture - University of Split.

Some certificates, issued after successful completion of training programme by legal persons that have been approved to conduct such training by the ministry in charge of physical planning and construction, are presented in Figure 3.

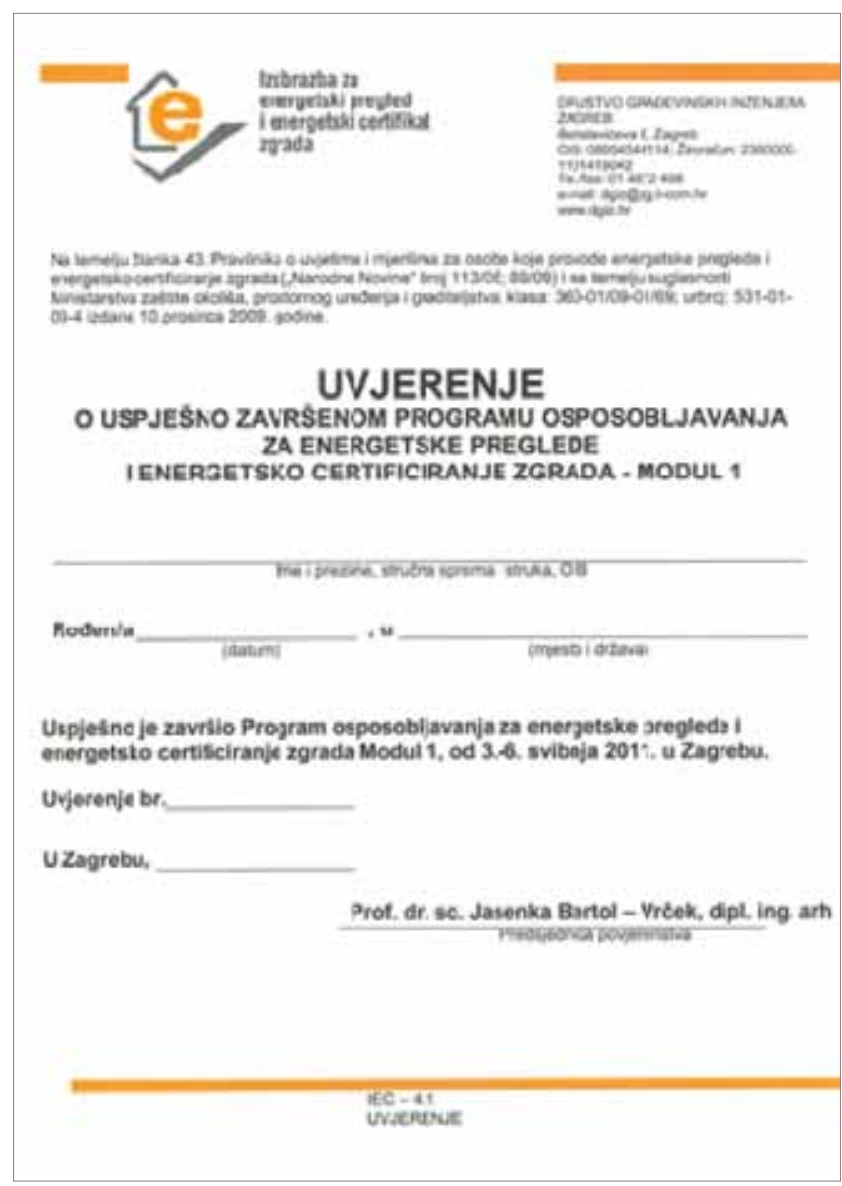

Figure 3. Example of certificate issued upon successful completion of training program (Society of Civil Engineers - Zagreb)

\section{Comparative overview of requirements for legal and physical persons}

Requirements for legal and physical persons (hereinafter: Persons) wishing to conduct energy audits for buildings (mechanical parts) for the purpose of issuing energy certificates for buildings, requirements for Persons wishing to conduct energy audits for buildings so as to fulfil obligations related to management of final consumption of energy (public sector buildings), and requirements for Persons wishing to conduct regular control audits for heating and air conditioning systems in buildings (for systems for which such obligation has been specified in the EPBD ॥ Directive), are defined in the Law on Physical Planning and Construction, in the Law on Efficient Use of Energy in Final Consumption, and in appropriate subordinate acts. Persons conducting such activities are registered either with the Register of persons authorized to conduct energy audits and energy certification of buildings (kept by the ministry in charge of physical planning and construction), or with the Register of persons authorized to conduct energy audits for buildings and control audits of heating and air conditioning installations for buildings (kept by the ministry competent for power sector).

Requirements set for experts conducting energy audits for buildings, energy certification for buildings, and regular control audits of heating and air conditioning systems for buildings, are presented in Table 2 .

The main difference in requirements is found in the training program: both in its content and duration.

\section{Conclusion}

Solutions presented in national regulations have been devised in accordance with requirements specified in relevant European directives, and include most recommendations from projects presented in this paper. The competence of experts is ensured by setting up appropriate requirements: level of education and profession, minimum working experience, prequalification, obligatory attendance of training programmes, examination, authorisation granted for a limited period of time, and continuous improvement. Through training programmes, experts improve their knowledge on energy efficiency of buildings by further extending their knowledge and by gaining additional knowledge from other professions, so that they can be able to view overall buildings as energy consumers. Through continuous improvement, experts are acquainted with latest accomplishments in the field of new materials and technologies, and with experience from practice. Training programmes must be uniformly defined and professionally implemented, while verification of knowledge is an additional requirement by which successful completion of programme, and acquirement of new knowledge and competences, is confirmed.

The work of authorised experts and legal persons in charge of training and improvement programmes must be checked so as to ensure proper quality of work, and to increase clients' trust in energy audits and energy certificates for buildings. Care must be taken to ensure that energy certification costs are appropriate, so as to achieve wide ranging application of costeffective measures aimed at improving energy characteristics of buildings. In this respect, it is highly recommended that energy audits of buildings and regular control audits of heating and air conditioning systems for buildings are harmonized with energy certification for buildings, and that they are implemented simultaneously, whenever possible.

Harmonization of requirements for experts, including training and improvement programs devised for such experts, will 
greatly contribute to development of the energy certification market within EU countries, and will increase quality of work and competition in this field. The harmonized training program for experts should include all modules contained in current two programmes and, depending on technical complexity of audits, this programme should enable development of more areas in which experts can be authorized. In case of highly complex energy audits for buildings, experts must have specialized knowledge that can not be acquired during 40 to 80 hours of training, which is why such audits should be reserved only for those experts that already possess formal education enabling

\section{REFERENCES}

[1] Action Plan for Energy Efficiency: Realising the Potential, http://ec.europa.eu/energy/action_plan_energy_efficiency/ doc/com_2006_0545_en.pdf.

[2] Directive 2002/91/EC of the European Parliament and of the Council of 16 December 2002 on the energy performance of buildings, Official Journal L 001, 04/01/2003 P. 0065-0071.

[3] Marđetko Škoro, N.: Upravljanje kvalitetom kod energijskog certificiranja zgrada, magistarski rad, Građevinski fakultet sveučilišta u Zagrebu, 2011.

[4] Directive 2010/31/EU of the European Parliament and of the Council of 19 May 2010 on the energy performance of buildings, Official Journal L 153, 18.06.2010, pp. 13-35.

[5] Directive 2005/36/EC of the European Parliament and of the Council of 7 September 2005 on the recognition of professional qualifications, text with EEA relevance, OJ I 255, 30.09.2005, p. 22.

[6] Directive 2006/32/EC of the European Parliament and of the Council of 5 April 2006 on energy end-use efficiency and energy services and repealing Council Directive 93/76/EEC (Text with EEA relevance), OJ L 114, 27.4.2006, pp. 64-85. them to conduct such energy audits. To take into account new requirements specified when proposing measures for increasing energy efficiency of buildings (optimum cost analyses), the education program should also be extended by including additional contents relating to economic assessment of proposed solutions, in order to increase energy efficiency. Extending program by including practical education such as visits to real-life buildings and partial conduct of energy audits, and greater use of computer tools with assessment of results gained during audit, will additionally enrich the education program and increase current level of competence of experts.

[7] Audit II topic report Energy audit models, www.motiva.fi/ files/1916/TR_EAM.pdf

[8] Detailed Report on training, Concerted Action, Supporting transposition and implementation of the Directive 2002/91/EC CA_EPBD (2007-2010)

[9] www.enforce-een.eu

[10] Zakon o učinkovitom korištenju energije u neposrednoj potrošnji, Narodne novine 152/08.

[11] Pravilnik o energetskim pregledima građevina, Narodne novine 5/11.

[12] Pravilnik o uvjetima za provođenje energetskih pregleda građevina, Narodne novine 5/11.

[13] Zakon o prostornom uređenju i gradnji, Narodne novine 76/07, 38/09, 55/11 i 90/11.

[14] Pravilnik o uvjetima i mjerilima za provođenje energijskih pregleda i energijsko certificiranje zgrada, Narodne novine 113/08 i 89/09. 